西機忠昭・久常雅世・川端麻衣子・中村秀美**

\title{
Recovery of Metal Values from Spent Nickel-Metal Hydride Secondary Batteries
}

\author{
Tadaaki NISHIKI, Masayo HISATSUNE \\ Maiko KAWABATA, Hidemi NAKAMURA
}

This paper describes the separation and recovery of metal values such as nickel, cobalt and rare earths from spent nickel-metal hydride (Ni-MH) secondary batteries. The containing metals (Ni, Co, rare earths, $\mathrm{Mn}, \mathrm{Zn}, \mathrm{Fe}$ ) in the batteries were efficiently leached by sulfuric acid solutions. By adjusting a pH of this leach liquor at around 3 , rare earths were recovered as a white precipitate. Solvent extraction and supported liquid membranes using PC-88A in kerosene were applied for separation and recovery of $\mathrm{Ni}$ and $\mathrm{Co}$ from the filtrate. We propose a composite process using the both techniques for the separation and recovery of metal values from spent Ni-MH secondary batteries.

1.はじめに

ニッケル/水素二次電池はクリーンエネルギーとして 各方面で用いられている。最近では、小型蓄電池として だけでなく、ハイブリッドカーの電源など大型電池とし ても用いられており、今後需要が增すものと考えられる。 このニッケル/水素二次電池には、コバルト、ニッケル、 希土類など多くの有価金属が含有されている。しかしな がら、本電池のリサイクル技術は確立されておらず、電 池を大量に使い捨てすることになれば、含有される有価 金属の消費量も增し、資源の枯渴が朢念される。そこで、 使用済みのニッケル/水素二次電池から有価金属を分離 回収するためのシステムの構築が緊急な課題となってい る。

溶媒抽出法は、連続的かつ大量に処理することができ、 工業的に非常に有効な分離法である。また、抽出法の一 種である支持液膜操作は、抽出試薬の使用量が極めて少 なくてすみ、正抽出と逆抽出を同時に行うことのできる 省エネルギ一的な高度分離技術として注目されている。

このような観点から、我々の研究室では、使用済み二 ッケル/水素二次電池から含有有価金属を分離回収する ことを目的として、電極からの硫酸による金属の浸出、 溶媒抽出および支持液膜操作による浸出液からの有価金 属の分離回収について検討を行い、金属有価物回収プロ セスの椿築を試みている。ここでは、その研究内容につ いて簡単に紹介する。

\footnotetext{
*平成 13 年 6 月 14 日 本会第 106 回例会において発表 **大阪府立大学大学院工学研究科物質系専攻

平成 13 年 4 月 10 日受理
}

\section{2. 電極からの金属の浸出}

ニッケル / 水素二次電池は、水酸化ニッケルを主成分 とする正極、水素吸蔵合金を主成分とする負極、および 水酸化カリウムを主成分とする電解液で構成されている。 各電極に含まれる金属を浸出するため、電池を解体して 得られた正極を約 $5 \mathrm{~mm}$ 角にしたサンプル、あるいは負 極を約 $3 \mathrm{~mm}$ 角にしたサンプル $2 \mathrm{~g}$ と所定量の硫酸水溶液 を三角フラスコに入れ、恒温槽 $\left(60,95^{\circ} \mathrm{C}\right)$ 中でマグネ チックスターラーにより一定時間 $(15,30,60,90,120$, $180,240 \mathrm{~min}$ ）擋拌接触させた。水溶液中の金属濃度を 測定し、浸出量を求めた。

負極からの浸出結果の一例を図 1 に示す。電極量 S [g] と硫酸液累 $\mathrm{L}[\mathrm{ml}]$ の比が $2 \mathrm{~g}: 40 \mathrm{ml}$ 、温度 $60^{\circ} \mathrm{C}$ 、浸出時 間 $180 \mathrm{~min}$ の結果である。浸出前の電極量 $2 \mathrm{~g}$ に対する漫 出した金属量 $[\mathrm{g}]$ の割合は、硫酸㜊度が高くなるにつれて 增大し、 $2 \mathrm{kmol} / \mathrm{m}^{3}$ 辺りで一定になった。また、液量、 温度などの影響を調べた結果、負極、正極いずれの場合 も、浸出に適した条件として次の結果が得られた。

$\mathrm{S}[\mathrm{g}]: \mathrm{L}[\mathrm{ml}]=2: 40$; 硫酸搌度 $2 \mathrm{kmol} / \mathrm{m}^{3}$; 温度 $60^{\circ} \mathrm{C}$; 時間 $60 \mathrm{~min}$

その条件下で得られた浸出液中の平均的な金属含有濃 度を表 1 にまとめた。

表に示した浸出液は、硫酸濃度が高いため、そのまま 溶媒抽出により金属を抽出することは因難である。そこ で、浸出液に $4 \mathrm{kmol} / \mathrm{m}^{3} \mathrm{NaOH}$ 溶液を加えて、 $\mathrm{pH} 4$ 程 度まで $\mathrm{pH}$ 調整を行った。その結果、負極浸出液の埸合、 $\mathrm{pH}=0.3$ 辺りから白色沈殿が発生した。また、調整後の 
溶液には La、Nd は含まれておらず、他の金属の含有寻 は調整前と変化なかった。このように、La、Nd などの 希土穎は沈殿物として回収可能である。一方、正極浸出 液では、 $\mathrm{pH}$ 調整前後で金属含有量の変化は見られなか った。

\section{3，溶媒抽出による金属回収}

浸出液中の金属を回収するために溶媒抽出の適用を検 討した。有機相には、抽出試薬として酸性リン化合物で ある 2-ethylhexyl 2-ethylhexylphosphonic acid (PC 88A）を含むケロシン溶液を、水相には、先述したよう に浸出液の $\mathrm{pH}$ を 4 に調整した溶液に等量の $\mathrm{CH}_{3} \mathrm{COOH} / \mathrm{CH}_{3} \mathrm{COONa}$ 緩衙液を加えた水溶液を用いた。 したがって、水相金属搌度は浸出液のほほ $1 / 4$ になって いる。等量の水相と有機相を擋汼接触させ、抽出分配平

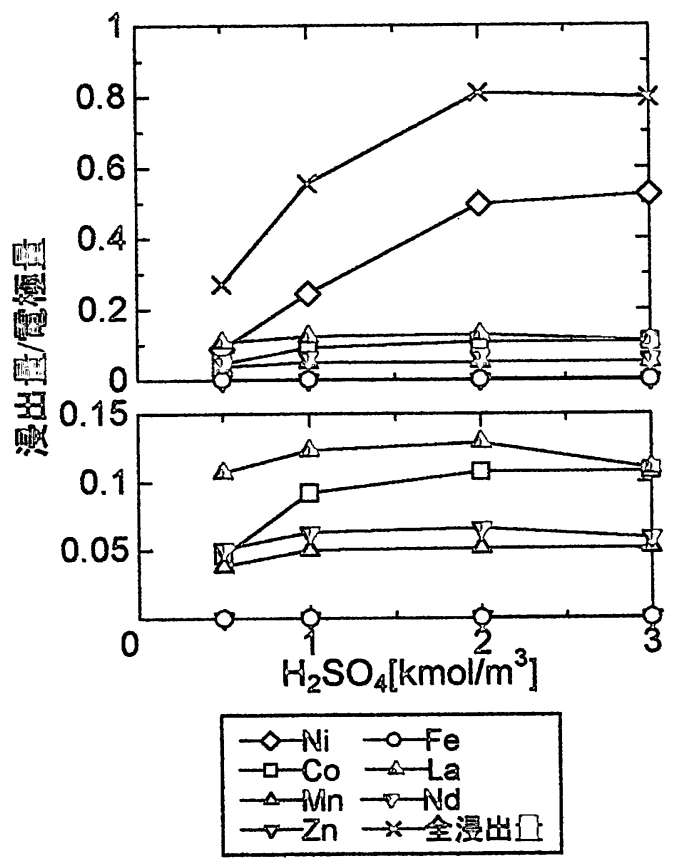

図 1 負極浸出における硫酸涱度の影響
衡を測定した。なお、PC 88A（HR）と 2 価の金属イオ ン $\left(\mathrm{M}^{2+}\right)$ は、油水界面で一般的に次のような反応をす る。

$$
\mathrm{M}^{2+}+2(\mathrm{HR})_{2} \rightleftarrows \mathrm{MR}_{2} \cdot 2 \mathrm{HR}+2 \mathrm{H}^{+}
$$

負極の浸出液に対する抽出平衡の結果を図 2 に示す。
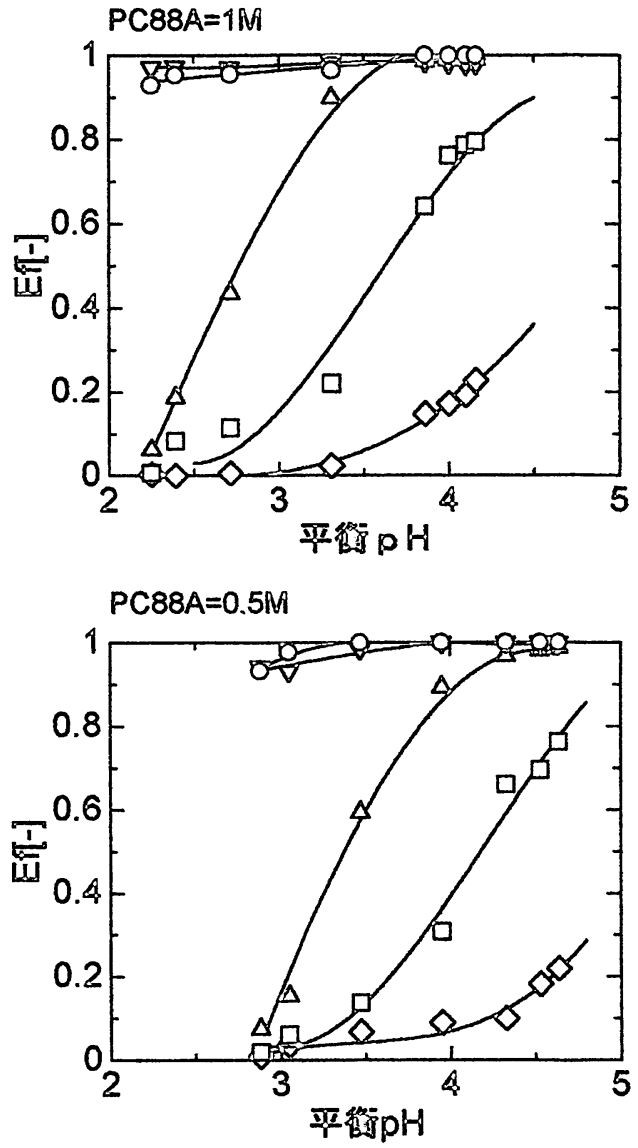

$$
\begin{array}{ll}
\diamond \mathrm{Ni}(0.1 \mathrm{M}) & \nabla \mathrm{Zn}(0.0001 \mathrm{MA}) \\
\square \mathrm{Co}(0.025 \mathrm{M}) & \circ \mathrm{Fe}(0.0001 \mathrm{M}) \\
\Delta \mathrm{Min}(0.01 \mathrm{M}) &
\end{array}
$$

図 2 負極浸出液に対する抽出平衡

表 1 浸出液中の金属含有港度 $\left[\mathrm{kmol} / \mathrm{m}^{3}\right]$

\begin{tabular}{lccllccc}
\hline & $\mathrm{Ni}$ & $\mathrm{Co}$ & $\mathrm{Mn}$ & $\mathrm{Zn}$ & $\mathrm{Fe}$ & $\mathrm{La}$ & $\mathrm{Nd}$ \\
負極 & 0.38 & 0.08 & 0.04 & 0.0005 & 0.002 & 0.04 & 0.02 \\
正極 & 0.40 & 0.03 & 0.0001 & 0.02 & 0.0004 & - & - \\
\hline
\end{tabular}


抽出率 $\mathrm{Ef}$ は、 $\mathrm{pH}$ の增大と共に增加し、PC 88A の源度 が高くなると大きくなっている。また、 $\mathrm{Fe}, \mathrm{Zn} \gg \mathrm{Mn}>\mathrm{Co}$ $>\mathrm{Ni}$ の順に抽出されやすいことがわかる。

図2 の結果より、まず水相から Fe、 Zn、Mn を有機相 に抽出し、次いで抽残液中の $\mathrm{Co}$ と $\mathrm{Ni}$ を分離することを 武みた。すなわち、 $0.5 \mathrm{kmol} / \mathrm{m}^{3}$ PC $88 \mathrm{~A} /$ /ケシン溶液 を用いて、平衔 $\mathrm{pH} 3.5$ で $\mathrm{Fe} 、 \mathrm{Zn} 、 \mathrm{Mn}$ を抽出し、その 抽残液から平衙 $\mathrm{pH} 4.5$ で Co を抽出した。その結果、最 終の水相には $\mathrm{Ni}\left(0.05 \mathrm{kmol} / \mathrm{m}^{3}\right)$ のみ残留したが、有機 相には Co 以外に $\mathrm{Mn}$ と $\mathrm{Ni}$ の一部が同時に抽出された。 このように、溶媒抽出操作のみで $\mathrm{Ni} 、 \mathrm{Co} 、 \mathrm{Mn}$ を分離す ることは困嚾であると推察された。そこで次に、支持液 膜操作の適用を検討した。

\section{4. 支持液膜による金属回収}

支持液膜とは、液膜相となる有機相を含浸させた多孔 質固体膜を異なる水相間に挟み込んだものである。PC 88A を担体として含むケロシン溶液を液膜相とする金属 イオンの透過は、図 3 に示したように、次の 5 つの過程 を経て原料相から回収相に透過する。(1)原料相側境膜の 金属イオンの拡散、(2)原料相側膜界面での正抽出反応に よる金属イオンと担体の錯体形成、(3)錯体の液膜相内の 执散、(4)回収相側膜界面での逆抽出反応による金属イオ ンの放出、(5)回収相側境膜の金属イオンの拡散。また、 水素イオンは金属イオンと逆方向に移動し、水素イオン をエネルギー源とする能動輸送により、金属イオンが回 収相側に源縮されることになる。

実験に使用した支持液膜装圈の概略を図 4 に示す。固 体支持膜としてテフロン製多孔質平膜（厚さ $125 \mu \mathrm{m}$ 、 細孔径 $10 \mu \mathrm{m}$ 、空孔率 $68 \%$ ）を採用し、細孔内に PC $88 \mathrm{~A}$

$$
\mathrm{M}^{2+}+2(\mathrm{HR})_{2} \leftrightarrow \mathrm{MR}_{2} 2 \mathrm{HR}+2 \mathrm{H}^{+}
$$

[M:金虽 HR:PC88A H:水窈]

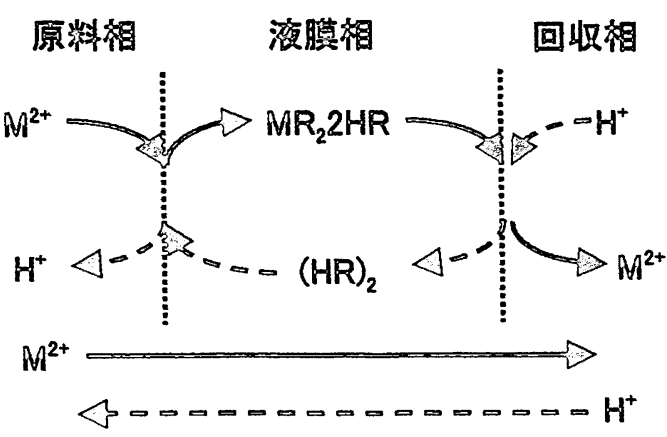

図 3 支持液膜を通しての金属透過モデル $\left(1.0 \mathrm{kmol} / \mathrm{m}^{3}\right) /$ /ケシン溶液を液膜相として含漫させ た。内径 $8 \mathrm{~cm}$ の二つのカラスセルの間に支持液膜を挟み 込み、左右のセルに原料相と回収相 $\left(0.5 \mathrm{kmol} / \mathrm{m}^{3}\right.$ $\mathrm{H}_{2} \mathrm{SO}_{4}$ ) を供給した。セル内の溶液は、直径 $4 \mathrm{~cm}$ の 6 枚 平羽根タービン罢を用いて 90 rpm で摫汼された。各セル の体程は $370 \mathrm{~cm}^{3}$ 、膜面䅡は $33.2 \mathrm{~cm}^{2}$ である。原料相 $(\mathrm{pH}$ 大）の金属イオンが液膜相を通して回収相（pH 小）に 移動する。

溶媒抽出により、浸出液中から $\mathrm{Fe} 、 \mathrm{Zn}$ を取り除いた 後、Mn、Co、Ni の分離に支持液膜を適用した。負極浸 出液から平衡 $\mathrm{pH} 2.3$ で $\mathrm{Fe} 、 \mathrm{Zn}$ を有機相に抽出し、 $\mathrm{Mn}$ 、 $\mathrm{Co} 、 \mathrm{Ni}$ を含む抽残相を $\mathrm{pH}=5$ に調整した溶液 $\left(\mathrm{C}_{\mathrm{Mn}}^{0}=0.005, \mathrm{C}_{\mathrm{C}_{0}}^{0}=0.01, \mathrm{C}_{\mathrm{Ni}}^{0}=0.05 \mathrm{kmol} / \mathrm{m}^{3}\right)$ を原料相 として支持液膜操作を行った。図 5 は、原料相および回 収相における各金属イオンの経時变化である。 $\mathrm{Ni}$ の初期 搌度が高いにも関わらず、回収相への移動は見られなか つた。したがって、本条件下での支持液膜操作では、 $\mathrm{Ni}$ は分離できるが、Mn と Co の分離は困難であると推察さ

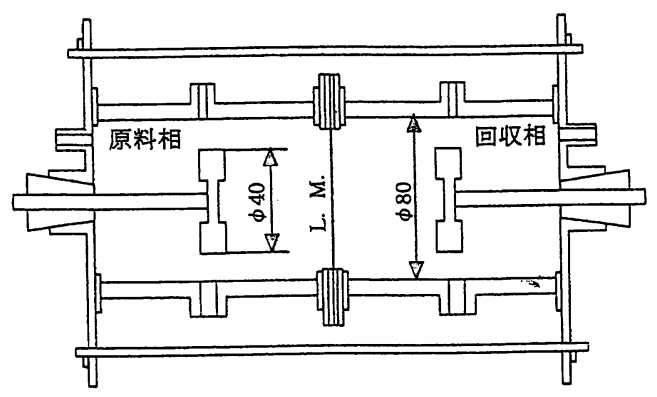

図 4 支持液膜装置

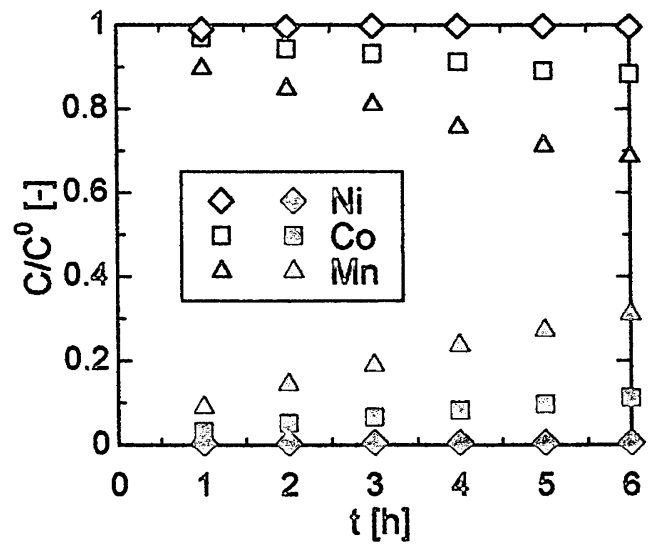

図 5 溶媒抽出後の負極浸出液に対する 支持液膜操作 
れる。そこで、溶媒抽出により $\mathrm{Fe} 、 \mathrm{Zn}$ と同時に $\mathrm{Mn}$ も 取り除くことを想定し、Co と $\mathrm{Ni}$ が共存する模擬溶液 $\left(\mathrm{C}_{\mathrm{C}_{0}}^{0}=0.01, \mathrm{C}_{\mathrm{Ni}}^{0}=0.05 \mathrm{kmol} / \mathrm{m}^{3}\right)$ を原料相として支持液 膜操作を行った。その結果を図 6 に示したが、Mn が共 存する図 5 と比皎して Co の透過速度が著しく速くなっ ている。これは、Coよりも透過しやすい $\mathrm{Mn}$ を取り除く ことで、Co の透過速度が增したものと思われる。また、 $\mathrm{Ni}$ については回収相への移動は見られず、Co と $\mathrm{Ni}$ の効 率的な分離が可能であることを示唆している。

\section{5．金属回収プロセス}

以上の結果を総合すると、電池の負極から有価金属を 分離回収するプロセスは図 7 のようになる。電池を解体 して得られる負極から硫酸により金属を浸出し、 $\mathrm{pH}$ 調 整を行うことにより希土類を沈殿物として回収する。次 いで、溶媒抽出により $\mathrm{Fe} 、 \mathrm{Zn} 、 \mathrm{Mn}$ を有機相に抽出した 後、Co と $\mathrm{Ni}$ を含む抽残液を支持液膜操作で処理して、 Coのみを回収相に移動させることにより $\mathrm{Ni}$ と分離する。 また、正極は希土郑を含んでいないことを除けば負極と 大差ないので、負極の場合と同様なプロセスの適用が可 能である。

\section{6. おわりに}

抽出試薬あるいは担体として PC 88A を用いた溶媒抽 出と支持液膜操作を組み合わせたプロセスにより、使用 済みニッケル/水素二次電池に含まれる有価金属を分離 回収できる可能性について示した。含有有価金属の搌縮 回収、使用試薬の低減などを図るために、プロセスの詳 細な検討ならびに改善が今後の課題である。

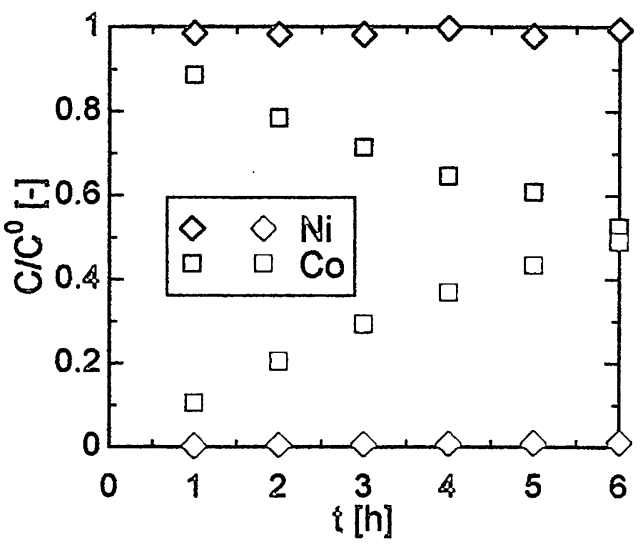

図 $6 \mathrm{Co}, \mathrm{Ni}$ 共存模擬溶液に対する 支持液膜操作

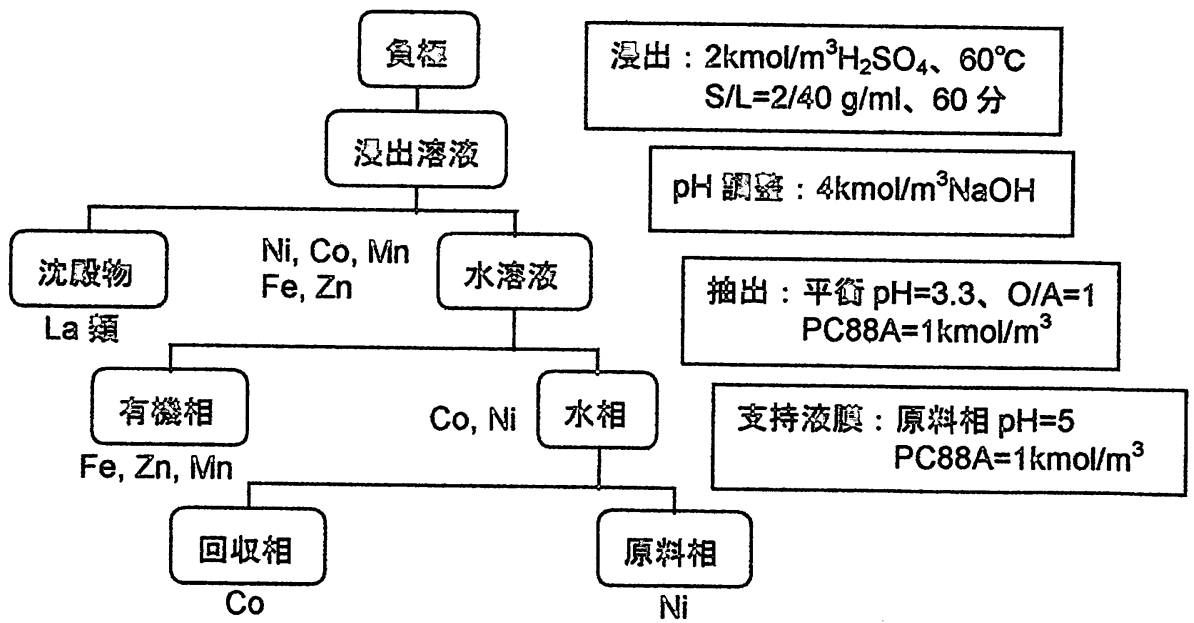

図 7 負極からの分離回収プロセス 